\title{
STATUTORY PRIMA FACIE EVIDENCE OF AGENCY IN AUTOMOBILE ACCIDENT LITIGATION: PROCEDURAL PROTECTION OF THE DEFENDANT
}

IN THE ABSENCE of ameliorative legislation, a party injured by an agent's negligent operation of a motor vehicle for his principal frequently finds it difficult to recover damages from the principal because the evidence necessary to establish the agency relationship lies solely within the knowledge of the principal and agent. ${ }^{1}$ North Carolina sought to remedy this situation in I95I by enacting a statute, Gen. Stat. section 20-7I.I, which provides that proof of the ownership or registration of a motor vehicle is prima facie evidence that the driver was acting as the owner's agent at the time of the accident. ${ }^{3}$ In its effort to assist

${ }^{1}$ The problem is well illustrated by Carter v. Thurston Motor Lines, 227 N.C. 193, 4I S.E.2d 586 (1947). The plaintiffs had been awakened by a loud noise and found a large commercial truck imbedded in the front of their home. The name of the defendant-motor line was painted on the truck and the driver was still at the scene. The plaintiffs were unable to prove the obvious fact of agency because they could produce no evidence that the driver was even employed by the truck's owner, nuch less that he was engaged in carrying out the business of the owner at the time of the accident. Because they were thus unable to prove an agency relationship between the driver and owner, the plaintiffs failed in their suit to recover from the motor line under the doctrine of respondeat superior.

${ }^{3}$ N.C. GEN. STAT. $\$ 20-71.1$ (1953): "Registration evidence of ownership; ownership evidence of defendant's responsibility for conduct of operation.-(a) In all actions to recover damages for injury to the person or to property or for the death of a person, arising out of an accident or collision involving a motor vehicle, proof of ownership of such motor vehicle at the time of such accident or collision shall be prima facie evidence that said motor vehicle was being operated and used with the authority, consent, and knowledge of the owner in the very transaction out of which said injury or cause of action arose. (b) Proof of the registration of a motor vehicle in the name of any person, firm, or corporation, shall for the purpose of any such action, be prima facie evidence of ownership and that such motor vehicle was then being operated by and under the control of a person for whose conduct the owner was legally responsible, for the owner's benefit, and within the course and scope of his employment. ..."

"At common law in North Carolina, a vehicle owner's liability under respondeat superior is predicated upon proof that the driver was the owner's agent and was acting within the scope of his employment at the time of, and in respect of, the transaction out of which the injury arose. Carter v. Thurston Motor Lines, 227 N.C. 193, 4r S.E.2d 586 (1947). In the Carter case, the court refused to follow those courts which permit an inference that a driver is a vehicle owner's agent to be drawn from the mere fact of the vehicle's operation and permit that inference to be used as a basis for an additional inference that the driver was acting within the scope of his employment at the time of, and in respect to, the accident. See Annots., 96 A.L.R. 634 (1935); 74 A.L.R. 95 I (193I); 42 A.L.R. 898 (1926). 
the injured party to prove the fact of agency, however, North Carolina may have given him an unwarranted advantage over the owner of the vehicle. The statute has been construed as raising a question for the jury whether the driver was acting as the owner's agent at the time of the accident, not only when there is no evidence relevant to that issue, apart from the permissible inference created by the statute, but also where there is uncontradicted evidence tending to show, no matter how strongly, that the driver was not acting as the owner's agent. ${ }^{4}$ Because the owner of the vehicle is thus placed at the mercy of the jury, the statute may exceed its purpose and unjustly expose him to liability unless the jury understands that the statute does not change the prerequisites of vicarious liability and that the prima facie evidence must be weighed against the other evidence in the case. ${ }^{5}$

In the case of Whiteside v. McCarson, ${ }^{6}$ the North Carolina Supreme Court sought to protect the interests of both the plaintiff and the owner of the vehicle and confine the statute to its proper purpose by invoking procedural requirements centered around the court's instructions to the jury. In that case the plaintiff presented evidence of the driver's negligence, but relied solely on the statute to establish the fact of agency. The evidence of the driver and the owner conflicted over whether the vehicle was operated with the owner's consent at the time of the accident, but the plaintiff presented no evidence that conflicted with the testimony of both the defendants that the driver was on a personal mission when the accident occurred. ${ }^{7}$ The owner having made

\footnotetext{
'See Travis v. Duckworth, 237 N.C. 47 I, 75 S.E.2d 309 (1953), where denial of the owner's motion for nonsuit was affirmed although there was evidence that the driver of a commercial truck was no longer about the owner's business when the accident occurred. The driver had disconnected the trailer portion of the truck and driven the cab 75 miles beyond his prescribed route to visit his home, injuring the plaintiff in an accident while en route.

${ }^{5}$ Candor compels acknowledgment that the greatest advantage given the plaintiff by this statute is the opportunity for an arbitrary jury verdict in his favor. Such an abuse of the jury's power may be combatted by a motion under N.C. GEN. STAT. \$ I-207 (1953), which permits the trial court to set aside a verdict based on insufficient evidence and award a new trial. Whether this motion will be granted, however, is within the trial court's discretion, and the Supreme Court is usually reluctant to hold that this discretion has been abused. See the concurring opinion of Barnhill, C.J., in Jyachosky v. Wensil, 240 N.C. 2 I $7,229,8$ I S.E.2d 644,652 (1954).

C 250 N.C. 673 , 1 10 S.E.2d 295 (1959).

The defendant-driver testified that he had borrowed the vehicle from his aunt, a sister-in-law of the defendant-owner, who frequently used the automobile and retained its keys. He also testified that his aunt had frequently loaned him the car with the owner's knowledge. The owner, however, testified that he had recently ordered that the car was not to be loaned to the driver again and that it was being operated without
} 
no requests for special instructions, the court charged the jury generally on the prerequisites of vicarious liability under the doctrine of respondeat superior and on the effect of the statute that raises prima facie evidence of agency. The jury was instructed to return a verdict for the owner of the vehicle if they should find the facts to be as the owner's evidence tended to show. ${ }^{8}$ They were not instructed, however, that the owner was not liable if the driver was on a personal mission at the time of the accident, even with the owner's consent. A verdict was returned against both the owner and the driver.

On appeal, the North Carolina Supreme Court reversed the judgment against the owner of the vehicle and remanded the case for a partial new trial on the issue whether the driver was acting as the agent of the owner at the time of the accident. The court held that when a plaintiff relies solely on Gen. Stat. section 20-7I.I to establish that the driver of a vehicle was acting as the owner's agent and the only positive evidence tends to show that the driver was on a personal mission, the owner is entitled to an instruction, related directly to the evidence in the case, that the jury must answer the issue of his liability in the negative if it finds the facts to be as his evidence tends to show. Thus, the trial court committed prejudicial error in failing to instruct the jury that, if they should find that the driver was on a personal mission at the time of the accident, with or without the consent of the owner of the vehicle, it would be their duty to return a verdict for the owner. ${ }^{9}$ Under the instructions given, the jury might have found the owner liable if they

his knowledge at the time of the accident. The aunt, testifying on the owner's behalf, corroborated the driver's testimony that he was on his way to pick up a girl for a date when he struck the plaintiff's car.

${ }^{8}$ This instruction was given in conjunction with the court's explanation of N.C. GEN. STAT. § 20-71.1 (1953), not with the summary of the owner's evidence. The jury was told that since the owner had introduced positive evidence to rebut the prima facie evidence raised by the statute, it would be their duty to return a verdict for him if they believed his evidence. The judge did not inform the jury which parts of the owner's evidence standing alone would be sufficient to warrant a negative answer to the issue of agency.

'In order to relate properly the law to the facts of the particular case, the instruction should be couched in more specific terms than stated above, e.g.: If you find that the defendant Melvin McCarson was proceeding to pick up a girl for a date at the time of the accident, with or without the consent of the defendant Robert Johnson, it will be your duty to answer the second issue [whether the driver was acting as the owner's agent] in the negative.

It would appear that the owner would also be entitled to an instruction informing the jury under what circumstances the automobile would be considered as having been driven without the owner's consent, since the absence of consent would also negate agency. 
disbelieved any part of his evidence. Thus, if they disbelieved the owner's testimony that the vehicle was driven without his consent, but believed that the driver was on a mission of his own, they might have held the owner vicariously liable without finding the essential fact of agency.

The owner's failure to request the omitted instruction did not excuse the court's failure to give it. Section I-180 of the North Carolina statute imposes upon the trial court the duty to "declare and explain the law arising on the evidence given in the case."10 This statute has been interpreted to require the judge, when charging the jury, to relate and apply the law to all the variant factual situations having support in the evidence, ${ }^{11}$ even in the absence of requests for special instructions. ${ }^{12}$

The possibility of the jury's becoming confused over the elements of vicarious liability may also be lessened by the proper formulation of the issues which, according to North Carolina practice, the jury is required to answer. ${ }^{13}$ The jury's attention is best focused on the true basis

\footnotetext{
${ }^{10}$ N.C. GEN. STAT. § I-I80 (1953): "No judge, in giving a charge to the petit jury, either in a civil or criminal action, shall give an opinion whether a fact is fully or sufficiently proven, that being the true office and province of the jury, but he shall declare and explain the law arising on the evidence given in the case. He shall not be required to state such evidence except to the extent necessary to explain the application of the law thereto; provided the judge shall give equal stress to the contentions of the plaintiff and defendant in a civil action, and to the State and defendant in a criminal action."

${ }^{11}$ Citizens Natl Bank v. Phillips, 236 N.C. 470,73 S.E.2d 323 (1952).

${ }^{12}$ Howard v. Carman, 235 N.C. 289, 69 S.E.2d 522 (1952). But see Paschal, A Plea for a Return to Rule $5 x$ of the Federal Rules of Civil Procedure in North Carolina, 36 N.C.L. REv. I (I957), an historical analysis of N.C. GEN. STAT. § I-1 8o (1953), which concludes that the current interpretation of this statute requiring judges to give unrequested instructions is incorrect.

The mandatory-instruction requirement of N.C. GEN. STAT. \$1-180 (1953), might produce a strange situation when a judge fails to give the instruction required by the Whiteside decision. The vehicle owner may elect not to object to the omission if he feels his position with the present jury is weak, knowing that a new trial is virtually assured by the error if the jury should find for the plaintiff. Under those circumstances, the plaintiff in the Whiteside case would have been forced to request that the jury be instructed to return a verdict for the owner if they believed the driver was using the automobile to date his girl. Since there was no conflicting positive evidence, such an instruction would have tended strongly to produce a verdict for the owner. Thus, in protecting an anticipated verdict, the plaintiff would have considerably jeopardized her chances of a favorable verdict.

${ }^{13}$ According to North Carolina practice, the issues raised by the evidence in the case may be submitted to the jury for separate verdicts. N.C. GEN. STAT. §§ 1-1961-200 (I953). In the Whiteside case, the issues submitted were: "I. Was the plaintiff Lois Whitesides injured and her property damaged by the negligence of the defendant [Iriver] Melvin McCarson, as alleged in the Complaint? ...2. Was the plaintiff
} 
of the owner's liability by the specific issue whether the driver was acting as the owner's agent at the time of the accident. The owner of the vehicle in the Whiteside case requested the submission of this issue, ${ }^{14}$ but the jury was asked only whether the plaintiff was injured by the negligence of the owner. The Supreme Court did not feel that this was prejudicial error in view of the accompanying instruction which explained the doctrine of respondeat superior. The court did comment, however, that the submission of an issue relating directly to the agency question would have more clearly presented the crux of the case to the jury. ${ }^{15}$

While the procedural practices prescribed by the Whiteside decision probably adequately insure that the jury will clearly understand the basis of the vehicle owner's liability for the negligence of the driver, they do not protect the owner from an arbitrary verdict for the plaintiff. Although this problem is not expressly considered in the Whiteside decision, it seems probable that fear of an arbitrary jury verdict was a prime reason for the court's seizing upon procedural devices to protect the defendant. ${ }^{16}$ The court thus seems to serve notice that when no other ground exists for setting aside an arbitrary verdict under section 20-7I.I, it may rest a reversal of the decision on the violation of some procedural requirement. ${ }^{17}$

Lois Whitesides injured and her property damaged by the negligence of the defendant [owner] Robert Johnson, as alleged in the Complaint? . . . 3. Did the plaintiff Lois Whitesides, by her own negligence, contribute to her injury and damage, as alleged in the Answers? . . . 4. What amount of damages, if any, is the plaintiff Lois Whitesides entitled to recover for her personal injuries? ...5. What amount, if anything, is the plaintiff Lois Whitesides entitled to recover on account of her property damage?" 250 N.C. at 675, r ro S.E.2d at 296.

14250 N.C. at 677,110 S.E.2d at 297 .

${ }^{15}$ Ibid.

${ }^{10}$ Former Chief Justice Barnhill expressed his concern with the effects of $\S 20-71.1$ in Jyachosky v. Wensil, 240 N.C. 217,81 S.E.2d 644 (1954). The jury had returned a verdict against the vehicle owner despite cogent evidence that the truck involved in the hit-and-run collision was not his, or that, if it was his truck, the driver was far from the prescribed route on a frolic of his own. The trial court had not set aside the verdict. The Chief Justice concluded that "While we need some statute such as G.S. $\S$ 20-7 I.I, this Act should be so amended as to afford the court an opportunity to grant relief in a case of this kind." 240 N.C. at 230 , 81 S.E.2d at 653 .

${ }^{17}$ In Parker v. Underwood, 239 N.C. 308, 79 S.E.2d 765 (1954), the court reversed a judgment for a plaintiff who had pleaded only the elements of which ownership is made prima facie evidence by part (a) of the statute, holding that the statute does not relieve the plaintiff of his obligation to plead and prove the elements of respondeat superior. This decision was rendered in spite of a prior decision in Hartley v. Smith, 239 N.C. 170,79 S.E.2d 767 (1954), that proof of ownership is adequate to raise prima facie evidence of the elements of respondeat stperior. The Harlley 
decision was based largely on a linguistic equation of the prima facie evidence raised by proof of ownership with the elements of respondeat superior. "Manifestly, the Legislature used the language 'was being operated and used with the authority, consent, and knowledge of the owner' to connote 'under the direction and control of the owner,' and when one acts under the direction and control of another, he is an agent or employee." Id. at 177,79 S.E.2d at 772 .

In Travis v. Duckworth, 237 N.C. 471, 75 S.E.2d 309 (1953), the court overturned a verdict against the owner of the vehicle by invoking a requirement that the jury be given a peremptory instruction to find for the plaintiff if they believe his evidence.

Finally, in Whiteside the requirement that the instruction be peremptory in form and relate the law to the facts of the particular case was invoked to overturn a verdict against the owner. 
